\title{
Angiotensin-Converting Enzyme Insertion/Deletion Polymorphism Does Not Influence the Restenosis Rate after Coronary Stent Implantation
}

\author{
Markus Ferrari ${ }^{a}$ Harald Mudra $^{b}$ Lars Grip $^{c}$ Vassilis Voudris $^{d}$ \\ Volker Schächinger ${ }^{e}$ Peter de Jaegere ${ }^{f}$ Johannes Rieber ${ }^{b}$ \\ Dirk Hausmann ${ }^{g}$ Martin Rothman ${ }^{\text {h }}$ Dietmar H. Koschyk ${ }^{i}$ \\ Hans R. Figulla ${ }^{a}$ on behalf of the OPTICUS ACE Substudy \\ ${ }^{a}$ Clinic of Internal Medicine, University of Jena, ${ }^{b}$ Clinic of Internal Medicine, University of Munich, Germany; \\ 'Division of Cardiology, University of Göteborg, Sweden; ' Onassis Cardiology Center, Athens, Greece; \\ e Clinic of Internal Medicine, University of Frankfurt, Germany; 'Department of Cardiology, University of Utrecht, \\ The Netherlands; 9Division of Cardiology, University of Hannover, Germany; ${ }^{\text {h}}$ Department of Cardiology, \\ London Chest Hospital, London, UK; 'Division of Cardiology, University of Hamburg, Germany
}

\author{
Key Words \\ Multicenter study · Genetics · Restenosis · \\ Coronary stents
}

\begin{abstract}
Background: Experimental studies have shown an activation of the angiotensin-converting enzyme (ACE) system as a response to endothelial injury. Recent publications have elucidated the hypothesis that the ACE gene polymorphism may influence the level of late luminal loss after coronary stent implantation. It is still unclear whether the polymorphism of the angiotensin gene is a major predictor of the extent of neointimal hyperplasia. In this multicenter study, we therefore tested the relationship between the ACE gene polymorphism and the restenosis rate after coronary stent implantation. Methods: As a substudy of the optimization with intracoronary ultrasound (ICUS) to reduce stent restenosis (OPTICUS) study, we analyzed ACE serum levels and the ACE gene polymorphism in 154 patients at 9 different centers. All patients underwent elective coronary stent implantation
\end{abstract}

\section{KARGER}

Fax +41613061234

E-Mail karger@karger.ch

www.karger.com

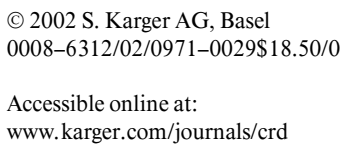

in a stenosis of a major coronary vessel. Balloon inflations were repeated until a satisfactory result was achieved in on-line quantitative coronary angiography or ICUS fulfilling the OPTICUS study criteria. After followup of 6 months, all patients underwent reangiography under identical projections as the baseline procedure. A blinded quantitative analysis of the initial procedure as well as the follow-up examinations were performed by an independent core laboratory. ACE gene polymorphism and ACE serum activity were measured at the 6month follow-up in a double-blinded setting. Results: With respect to the ACE gene polymorphism, there were three subgroups: DD genotype (48 patients), ID (83 patients) and II (23 patients). The subgroups did not differ in regard to age, gender, extent of coronary artery disease, stenosis length, initial degree of stenosis or degree of stenosis after stent implantation. In all, 39 patients $(25.3 \%)$ had significant restenosis: 12 DD patients (25.0\%), 18 ID patients (21.7\%) and 9 II patients $(39.1 \%)$ (odds ratio $2.164,95 \%$ confidence interval 0.853-5.493). We obtained the following results for ACE serum levels: $0.53 \mu \mathrm{mol} / \mathrm{l} / \mathrm{s}$ in the DD subgroup, $0.29 \mu \mathrm{mol} / \mathrm{l} / \mathrm{s}$ in the ID
Prof. Dr. med. H.R. Figulla

Klinik für Innere Medizin III, Friedrich-Schiller-Universitä

Erlanger Allee 101

D-07740 Jena (Germany)

Tel. +49 3641 939138, Fax +49 3641 939363, E-Mail hans.figulla@med.uni-jena.de 
subgroup and $0.09 \mu \mathrm{mol} / \mathrm{l} / \mathrm{s}$ in the II subgroup $(p<0.001)$. Multivariate logistic regression analysis of the influence of ACE gene polymorphism on the restenosis rate after coronary stent implantation adjusted for lesion length (>12 mm), ACE inhibitor or hydroxymethylglutaryl coenzyme $A$ reductase (CSE) inhibitor treatment, age, male gender, diabetes mellitus, hypertension, high cholesterol, family history, smoking and three-vessel disease did not uncover any statistic significance. Conclusions: In contrast to other study groups, we were unable to disclose that the DD polymorphism of the ACE gene was associated with a higher rate of restenosis after coronary stent implantation in this multicenter study. In addition, patients with higher ACE serum levels did not show a higher restenosis rate in this trial. We conclude that the pathogenesis of restenosis is a multifactorial process involving various genetic and nongenetic factors.

Copyright $(2002$ S. Karger AG, Basel

\section{Introduction}

After 20 years of coronary angioplasty, the development of restenosis is still an unsolved problem [1]. Stent implantation reduces the restenosis rate compared to conventional balloon angioplasty [2, 3]. However, even after optimized stent deployment under the guidance of intravascular ultrasound, relevant luminal loss still occurs [4]. Recently, the influence of the local angiotensin system and medical inhibition of the angiotensin-converting enzyme (ACE) on the prognosis after percutaneous transluminal coronary angioplasty has become a major object of research [5]. Stent implantation inhibits the process of remodeling after coronary angioplasty [6]. However, the enhanced neointimal hyperplasia after stenting remains a challenge in clinical research. Experimental studies have shown a relationship between serum angiotensin levels and the development of arteriosclerosis [7]. Animal experiments have demonstrated the ability of ACE inhibitors to reduce neointimal thickening after endothelial injury [8].

A genetic polymorphism in the ACE gene determines the serum ACE concentration [9]. It has also been suggested that this insertion/deletion (I/D) polymorphism of a 250-base-pair-long DNA sequence determines the restenosis rate after coronary stent implantation [10]. Furthermore, serum plasma activity of ACE has been thought to play a major role in the development of restenosis after coronary stent implantation [11].
However, these recent single-center studies were performed in selected patients. Blinded analysis of a multicenter study is still missing; therefore, the present investigation was undertaken.

\section{Patients and Methods}

The present study was designed as a substudy of a large multicenter angioplasty trial. It was the aim of the substudy to analyze the role of the ACE polymorphism in restenosis rates in a multicenter setting.

\section{Patient Selection}

The present study is a substudy of the optimization with intracoronary ultrasound (ICUS) to reduce stent restenosis (OPTICUS) study, in which the influence of ICUS on the long-term results after coronary stent implantation was investigated. The population consisted of 550 patients altogether. On the basis of the Multi-Center Ultrasound Stenting in Coronaries (MUSIC) study, the patients were prospectively randomized for optimal stent implantation under the guidance of intravascular ultrasound or quantitative coronary angiography [4]. The details of the OPTICUS study are described elsewhere [12].

Patient recruitment for the substudy was on a volunteer basis (inclusion rate 28\%). Nine European centers participated in the ACE substudy. Between January 1996 and January 1998, 154 patients with elective coronary stent implantation were included. All patients fulfilled the inclusion criteria of the OPTICUS study; i.e. patients who were scheduled to undergo elective coronary angioplasty of one lesion were eligible. Patients with stable angina [Canadian Cardiovascular Society (CCS) class I-III], unstable angina (Braunwald 1A2C) or silent ischemia were included. The lesion length had to be $\leq 25 \mathrm{~mm}$ and the vessel diameter had to be $\geq 2.5 \mathrm{~mm}$ (by visual estimation). We excluded patients with left main disease ( $\geq 50 \%$ lumen narrowing), angiographic evidence of thrombus, bifurcation lesion, significant side branch involvement ( $\geq 2.5 \mathrm{~mm}$ in diameter), Q-wave infarction or akinesia in the myocardium supplied by the vessel of interest, lesions of bypass vessels, lesions in a bifurcation and severe accompanying disease. All patients had to give written informed consent. The study was performed with the approval of each local ethical committee.

\section{Study Protocol}

Coronary angiography was performed in the standard manner by femoral approach with 6- to 8-Fr guiding catheters. After intracoronary injection of $0.2 \mathrm{mg}$ of nitroglycerin, quantitative coronary angiography of the target lesion was performed. After administration of 10,000 IU of heparin, the stenosis was predilated. Subsequently, a Palmaz-Schatz stent (Power Grip ${ }^{\mathrm{TM}}$ or Crown ${ }^{\mathrm{TM}}$, Johnson \& Johnson, Warren, N.J., USA) or a NIR ${ }^{\mathrm{TM}}$ stent (Boston Scientific Corp., Natick, Mass., USA) was implanted. Balloon inflations with a pressure of $\geq 14 \mathrm{~atm}$ were performed until the study criteria of optimal stent expansion were achieved. According to a randomization scheme, in half of the patients, an additional examination of the target vessel was performed by ICUS. Further details of the OPTICUS criteria are described elsewhere [12]. 
ICUS criteria of optimal stent expansion were: complete apposition of the stent over its entire length against the vessel wall, an instent luminal area (LA) of the proximal stent entrance $\geq 90 \%$ of the proximal LA, an in-stent minimal LA of $\geq 90 \%$ of the average reference LA [(proximal LA + distal LA) $/ 2$ ] or $\geq 100 \%$ of the reference segment with the lowest LA. In vessels with an in-stent minimal LA of $\geq 9.0 \mathrm{~mm}^{2}$, the cutoff value of the latest criterion was lowered by $10 \%$.

The medication appropriate to each individual consisted of nitrates, $\beta$-blockers, ACE inhibitors and lipid-lowering drugs. All patients received aspirin as standard medication and ticlopidine $250 \mathrm{mg}$ b.i.d. for 2 weeks.

\section{Follow-Up}

The follow-up period was 6 months. All patients underwent reangiography. The second procedure was performed under identical conditions as the baseline procedure with respect to the projections of fluoroscopy and intracoronary injection of nitroglycerin. Clinical events such as death, acute myocardial infarction, repercutaneous transluminal coronary angioplasty, bypass surgery or intracranial hemorrhage, as well as current medication, especially ACE inhibitors, for each patient were documented. Blood samples were taken for analysis of the ACE gene polymorphism and the serum ACE activity.

The late event rate was obtained by a final interview after 12 months.

\section{Quantitative Coronary Angiography}

The method of the quantitative coronary angiography analysis was described previously [13]. Offline quantitative coronary angiography was performed by an independent center in a blinded fashion. The results of the baseline procedure and the follow-up examination were analyzed in the same way. Automatic contour detection was performed with a geometric edge differentiation technique as described previously [14]. All values are mean values of the analysis of at least two orthogonal planes. The degree of stenosis was calculated as the relation between the minimal luminal diameter and the average luminal diameter of the proximal and distal reference segment.

\section{Blood Sample Analysis}

Six months after stent implantation, all patients underwent reangiography. At that time, we took blood samples for analysis of the ACE I/D polymorphism and analysis of serum ACE activity.

All patients were questioned with respect to ACE inhibitor treatment. ACE gene polymorphism and ACE serum activity were analyzed in a double-blinded setting by an independent laboratory.

Genome DNA was extracted from $200 \mu$ of whole blood with a standard kit (QUIAmp, Quiagen). The ACE gene I/D polymorphism was determined according to the method of Rigat et al. [9]. Plasma ACE activity was measured through quantitative kinetic determination by photometry at $340 \mathrm{~nm}$ after a sufficient amount of N-(3-[2Furyl]acryloyl)-Phe-Gly-Gly (FAPGG) substrate (Sigma Diagnostics) was added to the serum sample (150-200 $\mu$ l).

To avoid genotyping bias, we performed a second reassessment of the DNA samples of all DD patients using a primer pair that recognizes an insertion-specific sequence [15].

\section{Statistical Analysis}

All values are expressed as mean \pm standard deviation (SD). $p$ values were calculated using the paired Student's $t$ test for statisti- cal analysis of continuous variables within a group. Associations between groups were tested for using the two-tailed unpaired t test and Kruskal-Wallis test.

A p value $<0.05$ was considered statistically significant. Multivariate logistic regression analysis with a confidence interval (CI) of 95\% was performed using SPSS 10.0 (SPSS Inc.).

\section{Results}

Detailed results of the OPTICUS study are published elsewhere [12]. There was no difference between angiographic guidance and ICUS guidance of coronary stent implantation with respect to the restenosis rate and follow-up results. The outcome of the patients was not influenced by the type of stent.

\section{Baseline Results}

Between January 1996 and February 1997, 154 patients from 9 European centers were enrolled in the OPTICUS ACE substudy. All patients met the inclusion criteria. It was possible to implant a stent in all patients with an initially optimal result. The early gain after stent implantation was $2.0 \pm 0.36 \mathrm{~mm}$. We did not observe any acute myocardial infarction or other severe clinical event in the 154 patients of the substudy population during the baseline procedure. Demographic baseline characteristics are shown in table 1 .

\section{Follow-Up Results}

After an average of 6 months (range 5-8 months), all patients underwent reangiography with the same projections as at baseline. In 39 patients $(25.3 \%)$, we observed a significant late luminal loss of $\geq 50 \%$. As shown in figure 1, the restenosis rate among the II homozygotes showed a tendency to be higher compared to that in ID and DD individuals. However, logistic regression analysis of II versus DD/DI showed an odds ratio of 2.164 (95\% CI 0.853-5.493), which cannot be considered statistically significant in this study population. At baseline, all patients were comparable according to angiographic findings (table 2). Figure 2 shows the cumulative distribution curves of the three subgroups according to the ACE gene polymorphism.

At the 12-month follow-up, 24 patients (15.6\%) reported a cardiac event which had occurred between 6 and 12 months after stent implantation. Six patients $(12.5 \%)$ in the DD group, 14 patients (16.9\%) in the ID group and 4 patients (17.4\%) in the II group had suffered an event (no statistically significant difference). 
Table 1. Baseline characteristics

\begin{tabular}{lcllr}
\hline & All patients & DD & DI & \multicolumn{1}{l}{ II } \\
\hline Number & 154 & $48(31 \%)$ & $83(54 \%)$ & $23(15 \%)$ \\
Age, years & $61 \pm 9.9$ & $60 \pm 9.5$ & $62 \pm 10.0$ & $60 \pm 9.9$ \\
Males & $119(77.3 \%)$ & $40(83.3 \%)$ & $59(71.1 \%)$ & $20(87.0 \%)$ \\
Diabetes & $33(21.4 \%)$ & $11(22.9 \%)$ & $19(22.9 \%)$ & $3(13.0 \%)$ \\
Hypertension & $81(52.6 \%)$ & $27(56.3 \%)$ & $41(49.4 \%)$ & $13(56.5 \%)$ \\
Smokers & $40(26.0 \%)$ & $13(27.1 \%)$ & $21(25.3 \%)$ & $6(26.1 \%)$ \\
High cholesterol & $105(68.2 \%)$ & $35(72.9 \%)$ & $53(63.9 \%)$ & $17(73.9 \%)$ \\
Family history & $55(35.7 \%)$ & $16(33.3 \%)$ & $33(39.8 \%)$ & $6(26.1 \%)$ \\
CSE inhibitor treatment & $57(37.0 \%)$ & $17(35.4 \%)$ & $31(37.3 \%)$ & $9(39.1 \%)$ \\
ACE inhibitor treatment & $51(33.1 \%)$ & $14(29.2 \%)$ & $25(30.1 \%)$ & $12(52.2 \%)$ \\
& & & &
\end{tabular}

Subgroups were formed according to the ACE gene polymorphism (DD, DI, II). Values are mean \pm SD percentage of subgroup.

Table 2. Angiographic findings

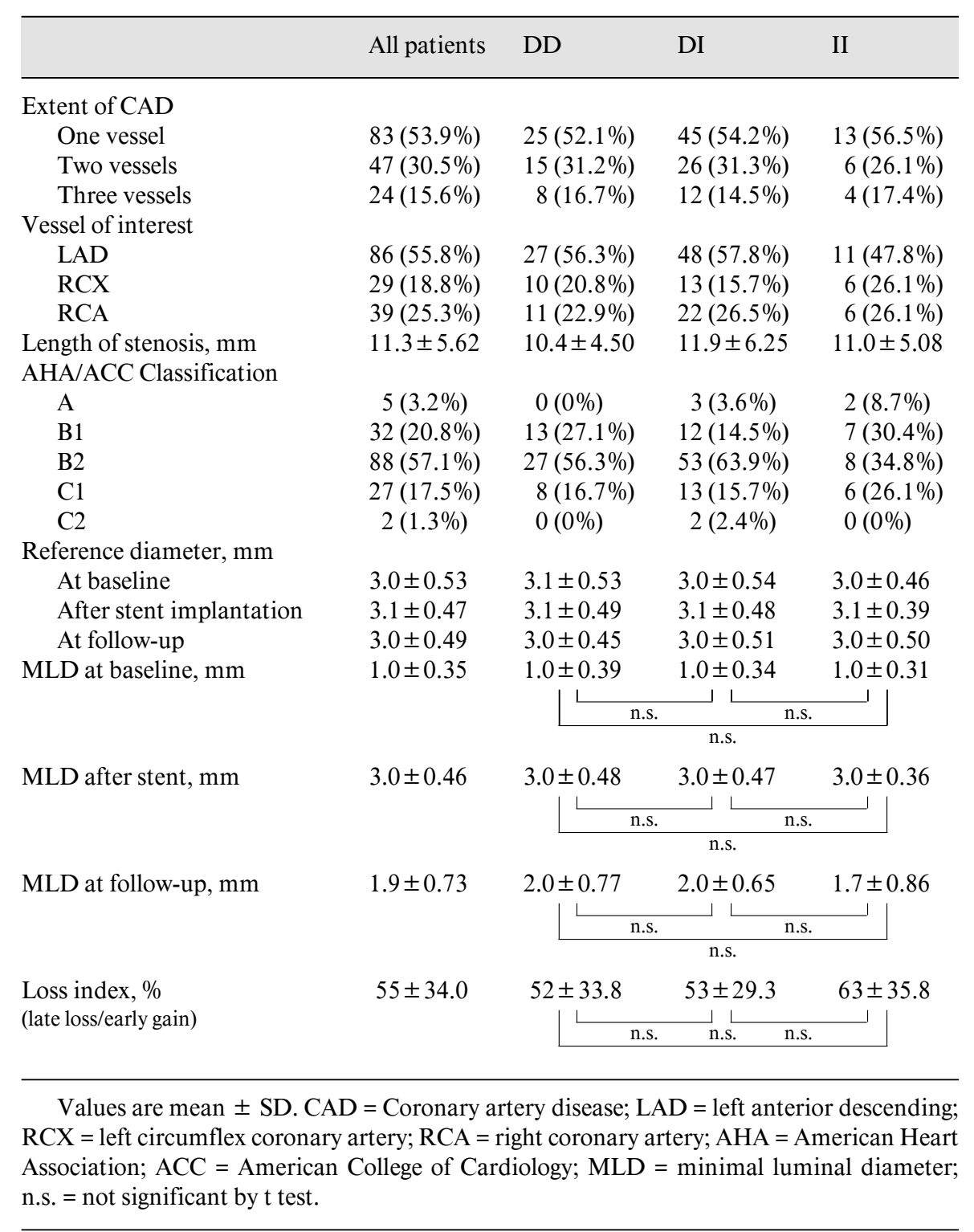


Fig. 1. Degree of stenosis before and after stent implantation and at follow-up in the three subgroups according to the ACE I/D genotypes (values are presented as mean \pm $\mathrm{SD})$.

Fig. 2. Cumulative distribution curves of minimal luminal diameter as a function of the ACE I/D genotype. a Before angioplasty (baseline) and after stent implantation (post stent). b After 6 months of follow-up (6MFU).
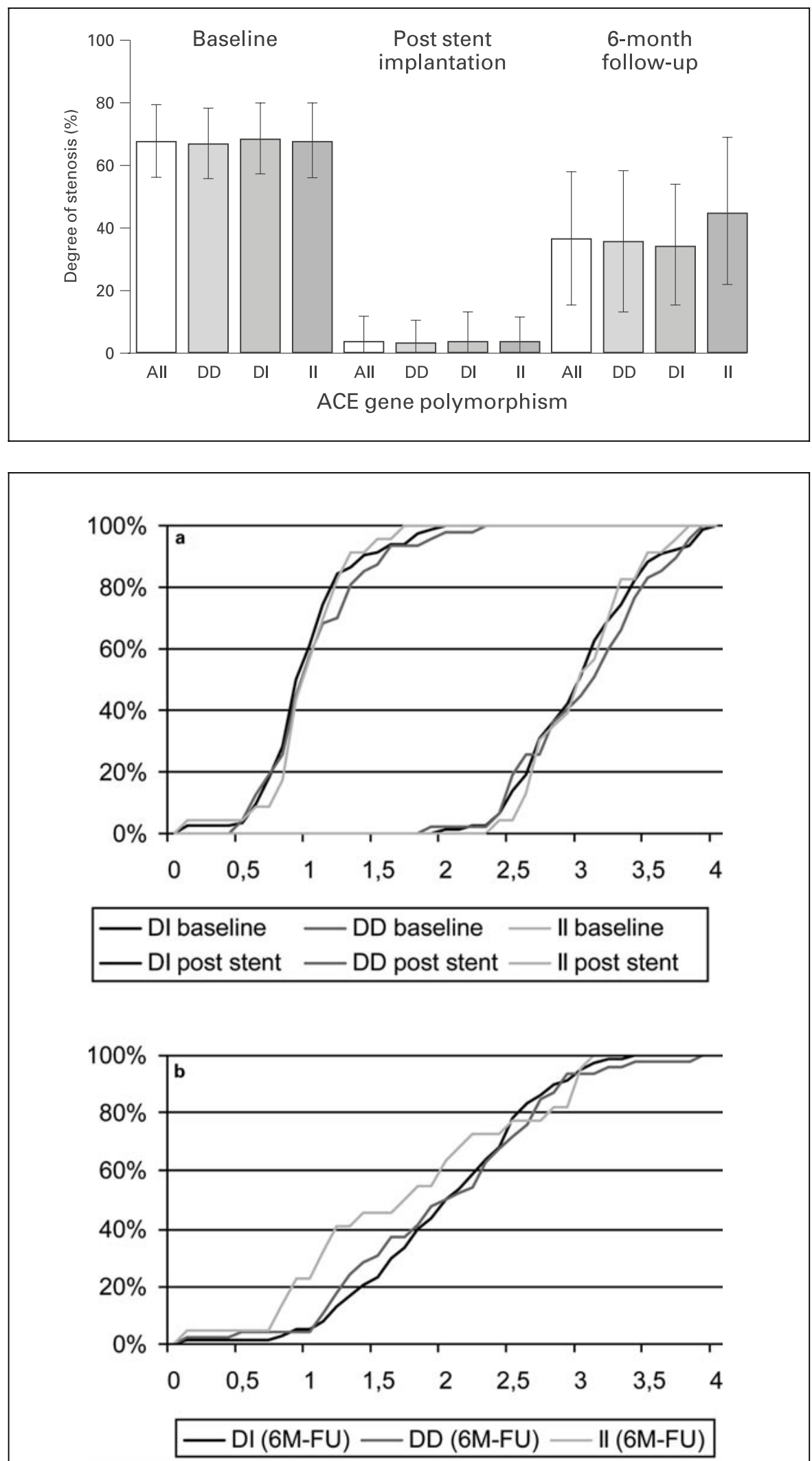
Table 3. Restenosis rate ( $\geq 50 \%$ diameter stenosis during follow-up) and serum ACE activity in patients with and without ACE inhibitor treatment

\begin{tabular}{|c|c|c|c|c|}
\hline & \multicolumn{4}{|c|}{ ACE activity, $\mu \mathrm{mol} / \mathrm{l} / \mathrm{s}$} \\
\hline & all patients & DD & DI & II \\
\hline \multicolumn{5}{|l|}{ No ACE inhibitor } \\
\hline All patients & $0.36 \pm 0.503$ & $0.55 \pm 0.421$ & $0.30 \pm 0.558$ & $0.10 \pm 0.067$ \\
\hline Patients with restenosis & $\begin{array}{l}0.30 \pm 0.325 \\
(\mathrm{n}=27 ; 26.2 \%)\end{array}$ & $\begin{array}{l}0.50 \pm 0.338 \\
(\mathrm{n}=9 ; 26.5 \%)\end{array}$ & $\begin{array}{l}0.23 \pm 0.305 \\
(\mathrm{n}=13 ; 22.4 \%)\end{array}$ & $\begin{array}{l}0.13 \pm 0.095 \\
(\mathrm{n}=5 ; 45.5 \%)\end{array}$ \\
\hline \multicolumn{5}{|l|}{ On ACE inhibitor } \\
\hline All patients & $0.30 \pm 0.402$ & $0.49 \pm 0.544$ & $0.26 \pm 0.287$ & $0.07 \pm 0.0072$ \\
\hline Patients with restenosis & $\begin{array}{l}0.33 \pm 0.427 \\
(\mathrm{n}=12 ; 23.3 \%)\end{array}$ & $\begin{array}{l}0.69 \pm 0.447 \\
(\mathrm{n}=3 ; 21.4 \%)\end{array}$ & $\begin{array}{l}0.11 \pm 0.025 \\
(\mathrm{n}=5 ; 20.0 \%)\end{array}$ & $\begin{array}{l}0.03 \pm 0.005 \\
(\mathrm{n}=4 ; 33.3 \%)\end{array}$ \\
\hline \multicolumn{5}{|c|}{ Patients with and without ACE inhibitor } \\
\hline All patients & $0.34 \pm 0.477$ & $0.53 \pm 0.462$ & $0.29 \pm 0.501$ & $0.09 \pm 0.070$ \\
\hline Patients with restenosis & $\begin{array}{l}0.31 \pm 0.356 \\
(\mathrm{n}=39 ; 25.3 \%)\end{array}$ & $\begin{array}{l}0.56 \pm 0.388 \\
(\mathrm{n}=12 ; 25.0 \%)\end{array}$ & $\begin{array}{l}0.21 \pm 0.283 \\
(\mathrm{n}=18 ; 21.7 \%)\end{array}$ & $\begin{array}{l}0.09 \pm 0.091 \\
(\mathrm{n}=9 ; 39.1 \%)\end{array}$ \\
\hline
\end{tabular}

Values are mean $\pm \mathrm{SD}$.

\section{Gene Polymorphism and ACE Serum Activity}

The serum ACE activity was 6 times higher in DD patients than in II homozygous individuals ( 0.53 vs. $0.09 \mu \mathrm{mol} / \mathrm{l} / \mathrm{s}$ ). Heterozygous patients (ID) had an average ACE activity of $0.29 \pm 0.501 \mu \mathrm{mol} / 1 / \mathrm{s}$. The ACE activities of all patients are depicted in table 3 , differentiating between those patients who were under medication with ACE inhibitors and those without ACE activity-influencing therapy.

\section{Statistical Analysis of Risk Factors}

Multivariate logistic regression analysis did not show any statistical significance for the ACE gene polymorphism as a risk factor of restenosis after stent implantation, including lesion length ( $>12 \mathrm{~mm})$, ACE inhibitor or CSE inhibitor treatment, age, male gender, diabetes, hypertension, high cholesterol, family history, smoking and three-vessel disease. The odds for DD patients and DI patients were 0.536 (95\% CI 0.119-2.411) and 0.486 (95\% CI 0.121-1.918), respectively.

The odds ratio for II patients compared to DD/DI patients was 2.164 , with a $95 \%$ CI of $0.853-5.493$.

Furthermore, the relative risk of restenosis did not show any correlation with the degree of restenosis nor the restenosis rate (odds ratio 1.002, 95\% CI 0.990-1.014).

\section{Discussion}

In this prospective multicenter study, we tested the hypothesis that the ACE gene DD/ID polymorphism is a predictor of restenosis after coronary stent implantation. In 154 patients at 9 different centers, we were unable to discover that those with the DD/ID polymorphism of the ACE gene had a higher extent of restenosis after coronary stent implantation compared to those with the II polymorphism. In addition, the ACE serum levels did not show any significant correlation with the restenosis rate.

\section{ACE Gene Polymorphism}

Recently published single-center studies have implicated an interaction of this polymorphism located in intron 16 of the ACE gene with the amount of late luminal loss after stenting in a selected group of patients [10, 11]. Several studies have shown a correlation between the ACE gene polymorphism and the extent of arteriosclerosis, while other studies have disproved this relationship [16-18]. A meta-analysis of 3,394 patients by Samani et al. [19] revealed an odds ratio of 1.26 for myocardial infarction among DD homozygotes compared to an ID/II population. Our findings are also supported by a recently published single-center study with a follow-up angiography rate of $84 \%$ [20]. In that study, Koch et al. [20] did not find any association between the polymorphism of the ACE gene and the restenosis rate after coronary stent 
placement. A retrospective analysis of the Framingham Heart Study showed an association between the ACE gene polymorphism and one major risk factor of coronary artery disease only in men but not in women [21]. DD homozygotes probably have an increased risk of arteriosclerosis and myocardial infarction if they show major risk factors like hypertension, hypercholesterolemia or diabetes mellitus [17, 22]. Individuals with $\mathrm{D}$ alleles also show a higher body fat mass compared to II homozygotes, which may also influence the cardiovascular risk profile [23]. However, most studies showing any correlation between ACE gene polymorphism and arteriosclerosis investigated a multifactorial process. The ACE system only plays a minor role compared to other factors of atherogenesis. The risk analysis of stent restenosis is even more complex, since major risk factors of coronary artery disease are not associated with a significantly elevated restenosis rate.

\section{ACE Serum Activity}

A correlation between the ACE serum activity and the restenosis rate after stent implantation has been brought up in a recently published study [11]. Animal experiments have shown that a reduction of ACE activity by medical treatment can reduce the amount of neointima formation in arteries of rats [5]. However, the dosage of ACE inhibitor used in the animal experiments was much higher than dosages endured by humans [7]. Lower doses of ACE inhibitor did not result in a reduction of the restenosis rate after balloon angioplasty [24, 25].

In our study population, there was no significant correlation between ACE activity and the restenosis rate after stent implantation. Although the ACE activity was lower among patients who received ACE inhibitors, the restenosis rate did not differ significantly compared to those without ACE inhibitor medication.

\section{Conclusion}

In this multicenter study, we disproved the hypothesis that the DD/ID polymorphism of the ACE gene is of importance in the development of restenosis after coronary stent implantation.

In addition, the ACE serum levels did not correlate with the restenosis rate. In vitro experiments as well as further studies with larger number of patients may give more insights into the multifactorial process of vascular remodeling and restenosis after coronary stent implantation.

We conclude that the pathogenesis of stent restenosis is a multifactorial process influenced by various genetic and nongenetic factors, but is not determined by the ACE gene polymorphism.

\section{References}

1 Holmes DR Jr, Vlietstra RE, Smith HC, Vetrovec GW, Kent KM, Cowley MJ, Faxon DP, Gruentzig AR, Kelsey SF, Detre KM: Restenosis after percutaneous transluminal coronary angioplasty (PTCA): A report from the PTCA Registry of the National Heart, Lung, and Blood Institute. Am J Cardiol 1984;53:77C$81 \mathrm{C}$.

2 Serruys PW, de Jaegere P, Kiemeneij F, Macaya C, Rutsch W, Heyndrickx G, Emanuelsson H, Marco J, Legrand V, Materne P, Belardi J, Sigwart U, Colombo A, Goy JJ, van den Heuvel P, Delcan J, Morel M: A comparison of balloon-expandable-stent implantation with balloon angioplasty in patients with coronary artery disease. Benestent Study Group. N Engl J Med 1994;331:489-495.

3 Fischman DL, Leon MB, Baim DS, Schatz RA Savage MP, Penn I, Detre K, Veltri L, Ricci D, Nobuyoshi M, Cleman M, Heuser R, Almond D, Teirstein PS, Fish RD, Colombo A, Brinker J, Moses J, Shaknovich A, Hirshfeld J, Bailey S, Ellis S, Rake R, Goldberg S: A randomized comparison of coronary-stent placement and balloon angioplasty in the treatment of coronary artery disease. Stent Restenosis Study Investigators. N Engl J Med 1994;331:496-501.
4 de Jaegere P, Mudra H, Figulla H, Almagor Y, Doucet S, Penn I, Colombo A, Hamm C, Bartorelli A, Rothman M, Nobuyoshi M, Yamaguchi T, Voudris V, DiMario C, Makovski S, Hausmann D, Rowe S, Rabinovich S, Sunamura M, van Es GA: Intravascular ultrasoundguided optimized stent deployment. Immediate and 6 months clinical and angiographic results from the Multicenter Ultrasound Stenting in Coronaries Study (MUSIC Study). Eur Heart J 1998;19:1214-1223.

5 Rakugi H, Wang DS, Dzau VJ, Pratt RE: Potential importance of tissue angiotensin-converting enzyme inhibition in preventing neointima formation. Circulation 1994;90:449-455.

6 Hoffmann R, Mintz GS, Dussaillant GR, Popma JJ, Pichard AD, Satler LF, Kent KM, Griffin J, Leon MB: Patterns and mechanisms of in-stent restenosis. A serial intravascular ultrasound study. Circulation 1996;94:1247-1254.

7 Powell JS, Clozel JP, Muller RK, Kuhn H, Hefti F, Hosang M, Baumgartner HR: Inhibitors of angiotensin-converting enzyme prevent neointimal proliferation after vascular injury. Science 1989;245:186-188.
8 Powell JS, Muller RK, Baumgartner HR: Suppression of the vascular response to injury: The role of angiotensin-converting enzyme inhibitors. J Am Coll Cardiol 1991;17(suppl B):137B-142B.

9 Rigat B, Hubert C, Alhenc-Gelas F, Cambien F, Corvol P, Soubrier F: An insertion/deletion polymorphism in the angiotensin I-converting enzyme gene accounting for half the variance of serum enzyme levels. J Clin Invest 1990;86: 1343-1346.

10 Amant C, Bauters C, Bodart JC, Lablanche JM, Grollier G, Danchin N, Hamon M, Richard $F$, Helbecque N, McFadden EP, Amouyel P, Bertrand ME: D allele of the angiotensin I-converting enzyme is a major risk factor for restenosis after coronary stenting. Circulation 1997;96:56-60.

11 Ribichini F, Steffenino G, Dellavalle A, Matullo G, Colajanni E, Camilla T, Vado A, Benetton G, Uslenghi E, Piazza A: Plasma activity and insertion/deletion polymorphism of angiotensin I-converting enzyme: A major risk factor and a marker of risk for coronary stent restenosis. Circulation 1998;97:147-154. 
12 Mudra H, di Mario C, de Jaegere P, Figulla HR, Macaya C, Zahn R, Wennerblom B, Rutsch W, Voudris V, Regar E, Hennecke KH, Schächinger V, Zeiher A: Randomized comparison of coronary stent implantation under ultrasound or angiographic guidance to reduce stent restenosis (OPTICUS Study). Circulation 2001;104:1343-1349.

13 Schächinger V, Zeiher AM: Quantitative assessment of coronary vasoreactivity in humans in vivo. Circulation 1995;92:2087-2094.

14 Zeiher AM, Drexler H, Wollschläger H, Just H: Modulation of coronary vasomotor tone: Progressive endothelial dysfunction with different early stages of coronary atherosclerosis. Circulation 1991;83:391-401.

15 Zee RY, Ridker PM, Stampfer MJ, Hennekens $\mathrm{CH}$, Lindpaintner K: Prospective evaluation of the angiotensin-converting enzyme insertion/ deletion polymorphism and the risk of stroke. Circulation 1999;99:340-343.

16 Gardemann A, Fink M, Stricker J, Nguyen QD, Humme J, Katz N, Tillmanns H, Hehrlein FW, Rau M, Haberbosch W: ACE I/D gene polymorphism: Presence of the ACE D allele increases the risk of coronary artery disease in younger individuals. Atherosclerosis 1998;139. 153-159.
17 Hosoi M, Nishizawa Y, Kogawa K, Kawagishi T, Konishi T, Maekawa K, Emoto M, Fukumoto S, Shioi A, Shoji T, Inaba M, Okuno Y, Morii $\mathrm{H}$ : Angiotensin-converting enzyme gene polymorphism is associated with carotid arterial wall thickness in non-insulin-dependent diabetic patients. Circulation 1996;94:704-707.

18 Agerholm-Larsen B, Nordestgaard BG, Steffensen R, Sorensen TI, Jensen G, TybjaergHansen A: ACE gene polymorphism: Ischemic heart disease and longevity in 10,150 individuals. A case-referent and retrospective cohort study based on the Copenhagen City Heart Study. Circulation 1997;95:2358-2367.

19 Samani NJ, Thompson JR, O'Toole L, Channer K, Woods KL: A meta-analysis of the association of the deletion allele of the angiotensinconverting enzyme gene with myocardial infarction. Circulation 1996;94:708-712.

20 Koch W, Kastrati A, Mehilli J, Bottiger C, von Beckerath N, Schomig A: Insertion/deletion polymorphism of the angiotensin I-converting enzyme gene is not associated with restenosis after coronary stent placement. Circulation 2000;102:197-202

21 O'Donnell CJ, Lindpaintner K, Larson MG, Rao VS, Ordovas JM, Schaefer EJ, Myers RH, Levy D: Evidence for association and genetic linkage of the angiotensin-converting enzyme locus with hypertension and blood pressure in men but not women in the Framingham Heart Study. Circulation 1998;97:1766-1772.
22 O'Malley JP, Maslen CL, Illingworth DR: Angiotensin-converting enzyme DD genotype and cardiovascular disease in heterozygous familial hypercholesterolemia. Circulation 1998;97: 1780-1783.

23 Montgomery H, Clarkson P, Barnard M, Bell J, Brynes A, Dollery C, Hajnal J, Hemingway $\mathrm{H}$, Mercer D, Jarman P, Marshall R, Prasad K, Rayson M, Saeed N, Talmud P, Thomas L, Jubb M, World M, Humphries S: Angiotensinconverting-enzyme gene insertion/deletion polymorphism and response to physical training. Lancet 1999;353:541-545.

24 Does the new angiotensin converting enzyme inhibitor cilazapril prevent restenosis after percutaneous transluminal coronary angioplasty? Results of the MERCATOR study: A multicenter, randomized, double-blind placebo-controlled trial. Multicenter European Research Trial with Cilazapril after Angioplasty to Prevent Transluminal Coronary Obstruction and Restenosis (MERCATOR) Study Group. Circulation 1992;86:100-110.

25 Faxon DP: Effect of high dose angiotensin-converting enzyme inhibition on restenosis: Final results of the MARCATOR Study, a multicenter, double-blind, placebo-controlled trial of cilazapril. The Multicenter American Research Trial With Cilazapril After Angioplasty to Prevent Transluminal Coronary Obstruction and Restenosis (MARCATOR) Study Group. J Am Coll Cardiol 1995;25:362-369. 